\title{
Creation of transport hubs for the increase in investment attractiveness of the city
}

\author{
Elena Vasilyeva ${ }^{1, *}$ \\ ${ }^{1}$ Moscow State University of Civil Engineering, 129337, 26, Yaroslavskoye Shosse, Moscow, Russia
}

\begin{abstract}
Effective transport infrastructure development is known to be one of the key aspects of sustainable development of modern city environment. Creation of transport hubs is expected to make a contribution to the improvement of transport infrastructure. Some practical examples of implementing of hubs in Moscow were considered. The article proves that the creation of the transport hubs, is capable to contribute to the sustainable urban development: to provide high social-and-economic living standards for inhabitants, to make changes of different types of transport fast and convenient, to eliminate "poor points" in the transport infrastructure, to reduce stoppers in the city, to provide inhabitants with the necessary number of parking spaces and also to become an additional source of income both for the city, and for commercial structures. It also will be able to increase the investment attractiveness and investment activity of the area in general. However, the author criticizes the current approach to the organization of investments into the hub projects. The public-and-private-partnership in its broad sense would allow dividing expenses, risks and profit within the project, and at the same time keeps the municipal property for the facility. Meanwhile the use of concession does not allow providing the maximum transport project efficiency.
\end{abstract}

\section{Introduction}

That is important for comfortable movement around the city not only to build new stations and lines of the underground or new highways, to reconstruct the railroad, but it is important to coordinate all these facilities into a common "knot" or hub, which will allow passengers to make changes, without wasting their time. For this purpose the programme for creation of the transport hubs (TH) has been adopted in Moscow.

The programme of development of the transport hubs (TH) in Moscow [1] started in 2011. It assumes creation of 271 facilities, 175 of which are capital structures. Till 2020 it is planned to construct more than 270 modern transport hubs by the means of which authorities of the capital plan to optimize the passenger stream among different types of transport in Moscow.

The following results are achieved at the moment:

- 134 capital TH are under maintenance;

\footnotetext{
*Corresponding author: elena.chibisova_metr@mail.ru
} 
- $55 \mathrm{TH}$ are decided to be created at underground stations at the expense of the municipal budget (The Targeted Investment Program (TIP)

- Investors are determined for $14 \mathrm{TH}$ projects

- Installation and construction works of technological character are being conducted at 6 TH.

Generally, these projects have to concern not only transport infrastructure, as they assume construction of housing, multipurpose complexes, shopping centers, office and other municipal and commercial facilities. Only many-tier parkings, improvement of the territory and sometimes social objects are related to transport and social infrastructure in these projects (for example, kindergartens which will transfer to the city subsequently). At full implementation of such projects the advantage for the urban development can be considerable [2].

\section{Materials and methods}

The author studied materials of the state unitary enterprise "Research and Design Institute of the Master Plan of Moscow", of the Complex of Urban Policy and Construction of Moscow, analytical materials of the First infrastructure company INFRA ONE, opinions of experts in the field of city development, assessment of the real estate, transport infrastructure. Examples of some TH in Moscow were analyzed. First of all it was necessary to define terminology and classification of TH and also to study their standard design.

The transport hub can be defined as a public space, which not only unites different types of transport: the underground, the railroad, the Moscow Central Ring (MCR) and land city transport, but also provides the area with necessary social infrastructure.

From the engineering point of view all $\mathrm{TH}$ can be divided into plane and capital ones.

1. The plane TH (intercepting parking)

That is the simplest type of the transport-and-intercepting hub. They are less expensive for implementation, they also facilitate the transport situation in short terms. (Fig. 1. Hereinafter the drawings are provided for studying in open access by the Complex of Urban policy and construction of Moscow [3].

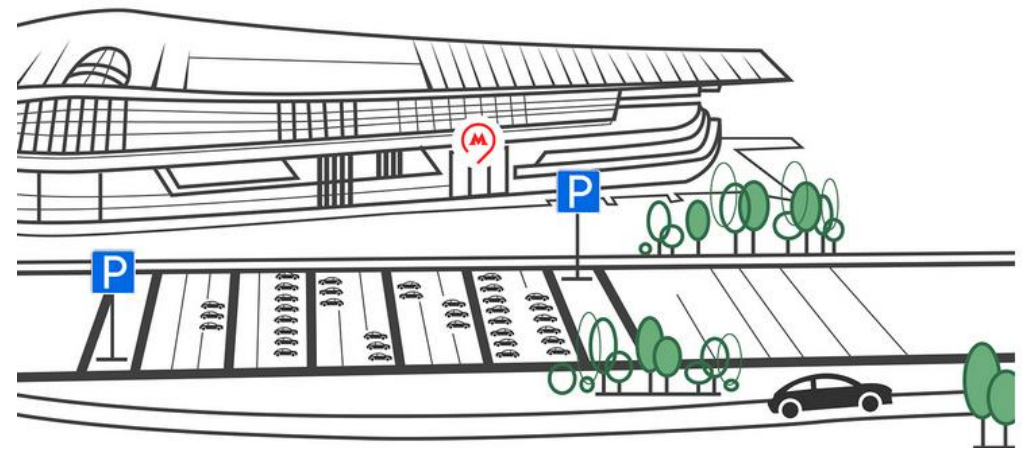

Fig. 1. Scheme of the intercepting parking [3].

The intercepting parkings have appeared at underground stations, remote from the centre, in order to replace the spontaneous stalls and chaotic parking. There new parking places are equipped, convenient walking paths and zones of expectation of city passenger transport and also clear navigation exist. Their main purpose of such hubs is to accept the transit individual transport of inhabitants of the capital region, who go to work to the centre of Moscow. The intercepting parking is free from 6:00 till 02:00. The payment is not raised in case of commission not less than two trips to the underground from the moment of statement of the car on the parking, according to one travel 
document, existing in the underground. The last entrance to the underground has to be carried out at the station, other than the station near which the intercepting parking is located. Thus, the benefit and appeal of such parking for the passengers is obvious.

2. Capital TH or "dry feet" principle

These TH are the whole structures and they demand more time for creation, than non-capital do. It is necessary for their construction to prepare the territory, city-planning documentation, to attract sufficient investments. In the capital TH passengers are protected from vagaries of the weather. They will be able to change types of transport, without leaving the chamber or pass through the covered pedestrian galleries. Such principle of is known as "dry feet" (Fig. 2).

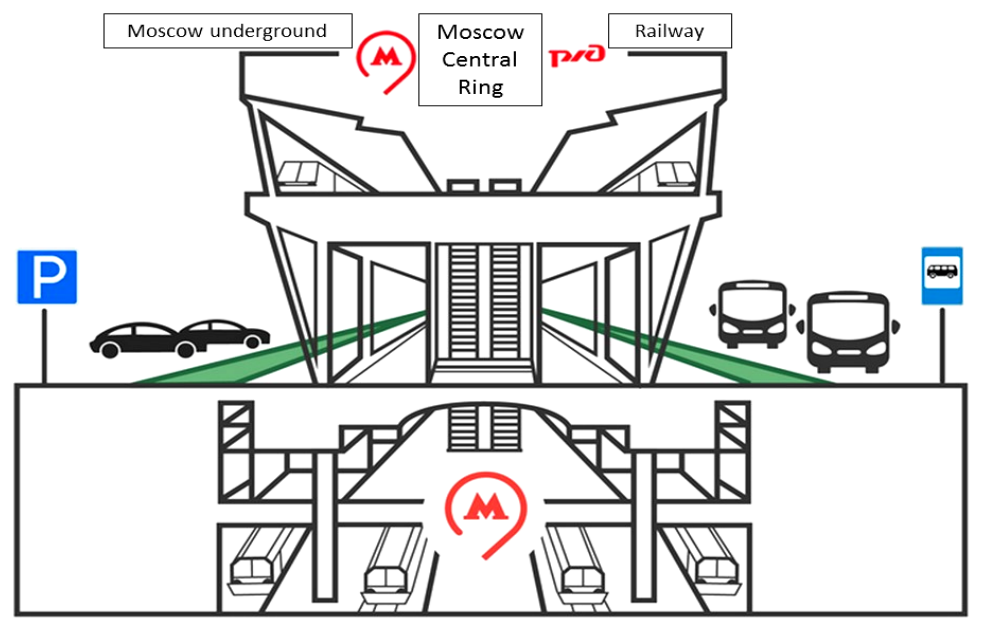

Fig. 2. Scheme of capital TH [3].

The building is designed so that the passengers, making change, do not have to make the way through shopping centres and offices. The commercial areas and zones of change will differentiate, large distributive halls will be equipped, the width of corridors and platforms of expectation will be calculated, depending on the passenger traffic.

Capital TH will become multipurpose, police stations, medical aid stations, shops, offices, housing, cultural objects are supposed in their structures (Fig. 3).

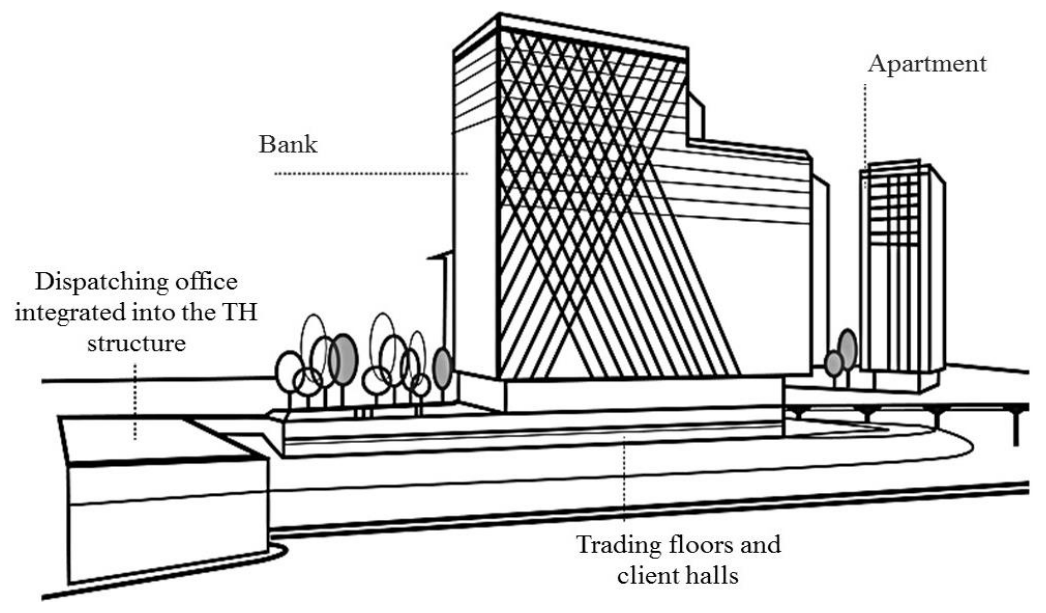

Fig. 3. Scheme of multipurpose TH [3].

Transport hubs can be also distinguished as:

- transport hubs of regional and international importance (airport, railway station etc.);

- Transport hubs of urban importance, including: 
- Inside the city (Comfortable interchange etc.)

- Outside the city (Situated on highway, includes shopping and entertainment center, spacious parking area, hotels etc.)

There is no standard set of objects which will settle down in the transport hubs - each TH is individual. The place and functionality are defined by specialists of the state unitary enterprise "Scientific-and-Research and Design Institute of the Master Plan of Moscow" on the basis of analytical data, proceeding from needs of the concrete area, load of the street road network and needs of inhabitants. For example, in the dormitory area it is expedient to build social objects, and in the new urban area it is possible to consider the possibility of housing construction $[4,5]$.

The analyses of practice proves, that the development of transport hubs is impossible without the established partnership between, municipal government (sometimes federal government) and private Sectors (fig. 4).

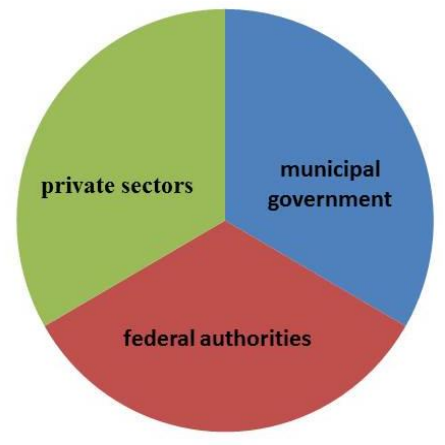

Additional revenue sources:

- Shops, galleries, cafes, restaurants;

- Business centers, offices;

- Parking;

- Advertising;

- Travel fare.

Fig. 4. Participants and TH projects financing.

Irrespective of the type all the Moscow transport hubs will be organized as rent with investment obligations. The private party redeems the design company, which is known as special purpose vehicle (SPV) or special purpose entity (SPE) [6,7], created by the city, and undertakes to construct some facilities on the site, localized for this company and for a certain term. The SPV price is quite symbolical - from several tens to 300 million rubles, but further the city will receive additional tax revenues. All the technological part of $\mathrm{TH}$ (construction and maintenance of capital-intensive transport infrastructure) Moscow (the municipal budget) undertakes.

\section{Results}

Numerous projects of transport infrastructure were studied within the research and their advantages / disadvantages for the municipal transport system and to the municipal budget were revealed (Table 1) [8-11].

Table 1. Examples of transport and infrastructure projects and their efficiency for the public party.

\begin{tabular}{|l|l|l|l|}
\hline \multicolumn{1}{|c|}{ Projects } & \multicolumn{1}{|c|}{ Content } & \multicolumn{1}{c|}{ Advantages } & \multicolumn{1}{c|}{ Financing } \\
\hline $\begin{array}{l}\text { paid parking } \\
\text { complexes } \\
\text { of different } \\
\text { types }\end{array}$ & $\begin{array}{l}\text { Projects of creation and } \\
\text { maintenance of municipal } \\
\text { parking complexes of } \\
\text { various types (automated, } \\
\text { mechanized, non- } \\
\text { mechanized, using different } \\
\text { number of storeys, with an } \\
\text { underground part, only } \\
\text { land, combined, etc.) }\end{array}$ & $\begin{array}{l}\text { Unloading of a street- } \\
\text { and-road network, } \\
\text { improvement of the } \\
\text { city spaces, additional } \\
\text { budget revenues }\end{array}$ & $\begin{array}{l}\text { Joint financing from the } \\
\text { budget is not required }\end{array}$ \\
\hline $\begin{array}{l}\text { Projects on } \\
\text { organization } \\
\text { of traffic }\end{array}$ & $\begin{array}{l}\text { Projects on creation of } \\
\text { overpasses over railway } \\
\text { lines }\end{array}$ & $\begin{array}{l}\text { Improvement of the } \\
\text { transport situation, the } \\
\text { increase in safety and }\end{array}$ & $\begin{array}{l}50 \% \text { and } 50 \% \text {, depending } \\
\text { on the facility type. In } \\
\text { some cases creation of }\end{array}$ \\
\hline
\end{tabular}




\begin{tabular}{|l|l|l|l|}
\hline & & $\begin{array}{l}\text { comfort for the } \\
\text { population, additional } \\
\text { budget revenues }\end{array}$ & $\begin{array}{l}\text { such facilities is possible } \\
\text { without any budgetary } \\
\text { investments. }\end{array}$ \\
\hline $\begin{array}{l}\text { Intercepting } \\
\text { parking }\end{array}$ & & $\begin{array}{l}\text { Unloading of a street- } \\
\text { and-road network, } \\
\text { improvement of the } \\
\text { city spaces, } \\
\text { integration of } \\
\text { passenger traffics } \\
\text { according different } \\
\text { types of transport }\end{array}$ & $\begin{array}{l}\text { About } 90 \% \text { of financing is } \\
\text { budgetary). }\end{array}$ \\
\hline $\begin{array}{l}\text { Capital } \\
\text { transport } \\
\text { hubs }\end{array}$ & $\begin{array}{l}\text { Implementation of projects } \\
\text { of construction of TH }\end{array}$ & $\begin{array}{l}\text { Integration of } \\
\text { passenger traffics } \\
\text { according different } \\
\text { types of transport, } \\
\text { attraction of private } \\
\text { capital into the } \\
\text { creation of separate } \\
\text { facilities of TH. }\end{array}$ & $\begin{array}{l}\text { Depending on the TH } \\
\text { type (90 ... 95\% of } \\
\text { financing remains } \\
\text { budgetary). }\end{array}$ \\
& & & \\
\hline
\end{tabular}

The main and most common advantages of $\mathrm{TH}$ for the Municipal transport infrastructure and for the urban development are the following $[12,13]$ :

1) Division of pedestrian and traffic flows (Fig. 5).

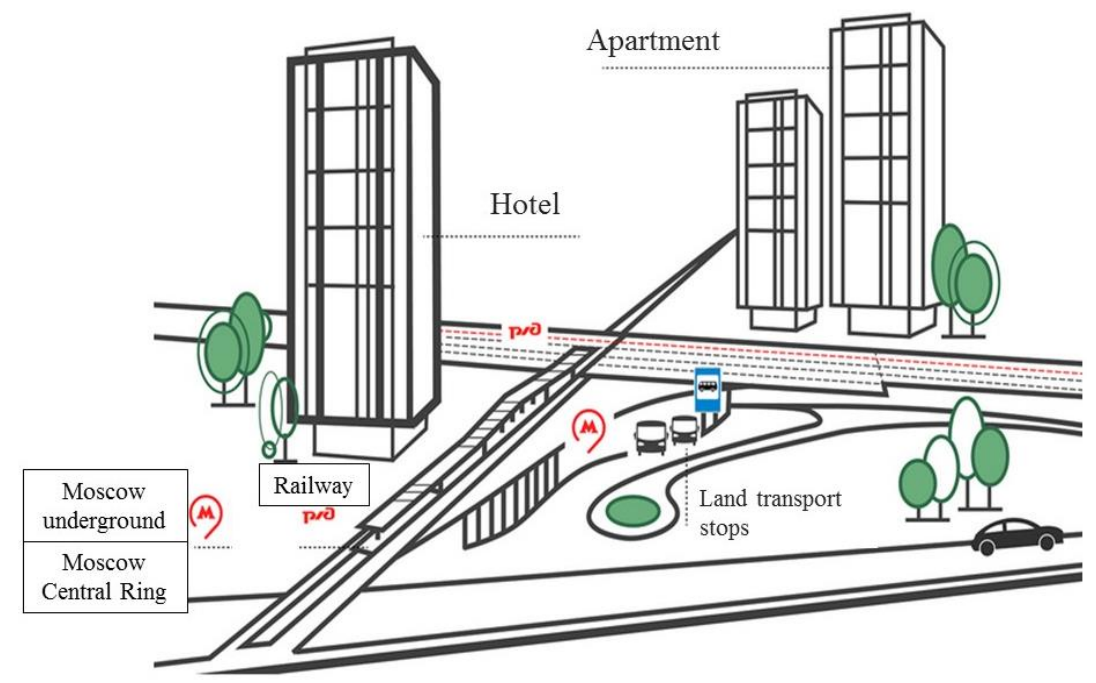

Fig. 5. Scheme of division of pedestrian and traffic flows [3].

2) Reduction of time of changing among types of transport.

3) Comfortable zone of change.

4) Refusal of the individual transport in favor of public. Reduction of traffic jams.

5) Organization of trade zones for the convenience of transients.

6) Availability for passengers, including handicapped people.

7) Convenient navigation.

8) Creation of new jobs.

9) Essential unloading of railway stations.

10) Better-planned territory. 


\section{Discussion}

The Moscow authorities, as well as investors, connect great hopes with TH. Even with input of only key hubs into maintenance, the transport situation in the city has to improve repeatedly: traffic jams will be gone, the number of parking spaces will increase, and people will quicker move though the capital. Shopping centers, offices, cafe, restaurants and change for any transport within several steps are, certainly, huge advantages. However, some experts doubt, that the neighborhood with $\mathrm{TH}$ will favorably affect the quality of accommodation and, respectively, demand for residential and office real estate in the respective district of the city.

Everything depends on concrete $\mathrm{TH}$, on where it is built, what will appear within its structure and what is its infrastructure content. If as a result of construction of a similar facility, the transport availability of those districts of the capital and the cities of Moscow area, where they are located, for example, improves new overpasses, platforms, road outcomes, metro stations, railway platforms appear, then, certainly, also the appeal of housing located in these locations increases further. If there are no essential changes, and only "modernization" of the transport infrastructure is carried out, for example, on the basis of the railway station an administrative complex for passengers is under construction, new parking spaces for cars and public transport are created and the territory, adjoining to them, equips with modern conveniences, then it practically does not affect the market of the residential real estate in any way.

However, some experts disagree, that demand for housing depends on the location of TH construction. According to some experts, demand for housing near TH depends not on their location, but on the consumer audience. The clients, focused on a rich-budget segment, most likely, will be indifferent to the TH existence near their housing, as they use privately owned vehicles, but not public transport.

That is also important, what will be the performance of the new transport hubs. If they acquire street trade, stalls, spontaneous parkings, warehouses and other unattractive infrastructure facilities, which usually adjoins to transport hubs and attracts unreliable social elements, then such TH, will push away buyers of the premium real estate. They will even cause the decrease in the investment attractiveness of the area $[14,15]$.

The buyers interesting in new buildings in the areas with the existing dense construction, which did not suffer from transport problems, earlier can face the similar situation $[16,17]$. There existing housing will fall in price, especially in the apartments with windows by stations and railway tracks. Accommodation near stops of public transport is conditional advantage since through $\mathrm{TH}$ daily there passes enormous traffic of people and cars that creates an additional noise background and in general reduces privacy and comfort of accommodation for inhabitants of such apartments. However, yet in primary real estate market there are no elite projects, which would be in the most direct proximity from facilities of transport infrastructure. Even if the rich-budget real estate is located close, for example the underground, it has a certain seclusion and privacy as it is usually constructed in quiet courts [19].

According to the author, the organization of investments into the TH construction is a subject for criticism.

In our opinion, the form, in which the project is implemented does not much promote attraction of private investments into the branch, it is rather directed to receiving commercial income from the development by private traders and collecting taxes by the city budget [20,21]. As a benchmark the calculation, which is carried out within the research for $8 \mathrm{TH}$ at Moscow Central Ring, assuming capital construction is indicative: even in case of maintaining the facilities structure during their transfer to concession, revenues of operators for the entire period of maintenance would be 150 billion rubles more 
(that is almost one third), than according to the current model. Moreover, as concession assumes such mechanism as "payment of the concessionaire", super profits could be divided with the city within the agreement. Besides, traffic intersections, separate elements of the underground and the other accompanying infrastructure could become a part of concession. At their expense that would be possible to reduce investments from the municipal budget.

The full-fledged public-and-private partnership in this sphere would have ampler opportunities, than the concession agreement. Advantage of public-and-private partnership is that, the risks, expenses and profit are distributed between both parties, besides advantage of public-and-private; partnership consists in maintaining the property right to the subject of the agreement.

\section{Conclusion}

The analysis of the programme of creation of TH in Moscow and studying of the realized projects proves, that they can contribute to the urban development considerably.

Certainly, that is necessary to mention that as for the creation of $\mathrm{TH}$ in luxurious districts of the city:

a) it is undesirable (because of violation of architectural-and-historical unity, because of depreciation of housing and the commercial real estate),

b) it is inexpedient, since the inhabitants of rich areas need any development of municipal transport infrastructure much less.

Nevertheless, as for the mass segment, construction of $\mathrm{TH}$, certainly, will become advantageous, especially in the suburbs of Moscow, where the development of transport infrastructure strongly influences housing cost, the size of rent of offices and investment attractiveness of the area in general.

As for organizational-and-economic aspect of the TH creation, it is imperfect. The concession model appears to be insufficiently effective from the point of view of municipal financing. It is improbable, that any cardinal changes in policy of Moscow, on the TH creation will happen in the next years, but according to the author, separate experiments with the concession model are possible on the horizon of one and a half or two years.

\section{References}

1. InfraONE Company, New Infrastructure Markets and Unimproved Opportunities of Old Ones. What Investment Potential Does Private Capital Have and what Restrictions Does it Face? Analitical Review (SPIEF, St. Peterburg, 2017)

2. Complex of Urban Policy and City Construction of Moscow News, legislative, methidical and analitical data, https://stroi.mos.ru/news/moskva-profinansiruietstroitiel-stvo-55-tpu?from $=\mathrm{cl}$ (2018)

3. H.T. Phuong, E. Scherbina, Basic research 7, 373-378

4. E. Sherbina, N. Danilina, D. Vlasov, International Journal of Applied Engineering Research 10(22), 43131-43138 (2015)

5. E. Vasilyeva, I. Polyakova, MATEC Web of Conferences 106, 08097 (2017)

6. I. Polyakova, E. Chibisova, Economy and entrepreneurship 5(70), 579-582 (2016)

7. H. Diell, Hebezeuge und Forderm 27(2), 44-45 (1987)

8. V. Carbone, Maritime Policy \& Management 30(4), 305-320 (2003)

9. I. Polyakova, E. Chibisova, Economy and entrepreneurship 4-1(69-1), 816-819 (2016) 
10. A. Mottaeva, MATEC Web of Conferences 106, 08072 (2017)

11. I. Polyakova, E. Vasilyeva, N. Vorontsova, IOP (Earth and Environmental Science) 90, 012136 (2017)

12. N. Evreenova, World of Transport and Transportation 5, 170-176 (2014)

13. M. Panteleeva, S. Borozdina, MATEC Web Of Conferencies 106, 08047 (2017)

14. M. Panteleeva, S. Borozdina, MATEC Web Of Conferencies 106, 08048 (2017)

15. E. Vasilyeva, T. Sazonova, IOP (Earth and Environmental Science) 90, 012116 (2017)

16. A. Seleznev, A. Mottaeva, L. Andreeva, S. Izmaylova, IOP Conference Series: Earth and Environmental Science 90(1), 012117 (2017)

17. E. Vasilyeva, A. Zlentenkov, O. Suzneva, E. Sapozhnikova, IOP (Earth and Environmental Science) 90, 12122 (2017)

18. R. Milner, Calculus of Communicating Systems (Berlin-Heidelberg-New York, Springer-Verlag, 1980)

19. D. Vlasov, Academia. Architecture and construction 3, 86-89 (2013)

20. A. Bahauovna, A. Bahauovna, International Journal of Applied Engineering Research 10(23), 43446-43449 (2015)

21. D. Radushinsky, A. Mottaeva, L. Andreeva, G. Dyakova, IOP Conference Series: Earth and Environmental Science 90(1), 012137 (2017) 